\title{
Biodegradation of Acetamiprid by both free and immobilized Lysinobacillus macrolides strain MSR-H10 in soil
}

\section{Ibrahim M. Gomaa ${ }^{1}$, Maged M. Saad ${ }^{2}$, Hend. A. Mahmoud ${ }^{3}$ and Hanaa A. Abo- Koura $^{4 *}$}

${ }^{1}$ Department of Environment and Bio-agriculture, Faculty of Agriculture, Al-Azhar University, Cairo, Egypt.

${ }^{2}$ Agricultural Genetic Engineering Research Institute (AGERI), Agricultural Research Center (ARC) Giza, Egypt.

${ }^{3}$ Central Laboratory of Residue Analysis of Pesticides \& Heavy Metals in Food, Agricultural Research Center (ARC) Giza, Egypt.

${ }^{4}$ Department Agricultural Microbiological Research, Soils, Water and Environment Research Institute (SWERI), Agricultural Research Center (ARC), Giza, Egypt.

*Corresponding authors: Ibrahim_gomaa79@yahoo.com

\begin{abstract}
Neonicotinoids are a commercial insecticides used worldwide in agriculture and are one of the major environmental pollutants. The prospective toxicity of the residues present in environment to humans has expected considerable attention. In this study, fifteen bacterial isolates were isolated from the soil sample, and tested for their Acetamiprid degrading capacity on MSM media containing Acetampirid as the sole carbon source. Lysinobacillus macrolides strain MSR-H10 was identified using 16S rRNA as one on the best performing isolates. The effects of $\mathrm{pH}$, temperature and agitation speed on the degradation efficiency of acetamiprid were investigated. Results indicated that L. macrolides is able to grow at different $\mathrm{pH}$, temperature and agitation speed. Interestingly, immobilized bacteria with sodium alginate recorded highest performance for growth compared to free bacteria and was able to grow in two types of soil containing different concentration of acetampirid. The immobilized bacteria were found to be used efficiently for the degradation of acetamiprid consecutively without any decrease in their efficiency. Hence, L. macrolides has a great efficiency for the degradation of acetampirid at concentration $5 \mathrm{mg} / \mathrm{L}$ after 21 days from incubation period in clay soil.
\end{abstract}

Keywords: Bioremediation, Immobilization; Sodium alginate; acetampirid biodegradation, PGPR. 


\section{Introduction}

Neonicotinoids have been commonly used in the world since 1990s. Until now; neonicotinoids are representing $25 \%$ of the global insecticide market (1). Acetamiprid (AAP) is one of the first-generation neonicotinoid insecticides, and neonicotinoid insecticides have been used for the last two periods as they are less toxic than older insecticides. In recent research, neonicotinoids had some delicate dangerous effects on bees (2) and (3) and neonicotinoid residues were detected in surface water $(4,5)$, wetland and soils. AAB causes acute and chronic toxicity in mammals and, moreover, a common method of action: mimicking the action of neural transmitters affecting the central nervous system, resulting in paralysis and death (6). In agricultural, acetamiprid are usually applied as insect controls, principally in seed treatments for crops, like corn, soybean and cereals. The residues cause direct or indirect effects on vertebrate wildlife (7).

Consequently, neonicotinoid insecticides can pollute soil and water and accumulate in the food chain. Increasing lines of sign show that these neonicotinoid insecticides cause harm to organisms, such as honeybees and wild bees, and these outcomes have prompted increasing concerns about these insecticides $(8,9)$. In recent years, acetamiprid residues in crops are receiving considerable attention because of their potential toxicity to humans $(10,11)$. Pesticides are inherently toxic molecules and have the potential to cause harm to the environment if not used properly. Though, their use in agriculture is inevitable, especially in developing countries to sustain the growing population. When a pesticide is applied in the field a major amount falls on to the soil surface, the contamination potential of any pesticide depends on its residential period in soil. Hence, it is necessary to study the determination behavior of pesticides in soil (12). Bioremediation, which involves the use of microbes to detoxify and degrade pollutants, has received increased attention as an effective biotechnological approach to clean up polluted environments (13). Studies of microbial degradation are useful for the development of bioremediation processes to detoxify pesticides to concentrations lower than the standards established by regulatory authorities (14).

The usage of pesticides to protect crops might alter the soil biological ability either by direct or indirect action, but the knowledge of soil microbial ability to degrade pesticides and the influence of pesticides on microbial diversity in soil is still narrow (15), the fertility of soil depends not only on the textures of soil but also on the biological ability within it. The microbial diversity can have been changed following pesticide use, and such changes could affect soil fertility (16). Some pesticides encourage the growth of microorganisms, but other pesticides have depressive effects or no effects on microorganisms. Use of Phosphoric insecticides such as Dursban and Cardona managed to the revitalization of soil microbes. While the other types of Phosphoric insecticides have shown an increase in the numbers of fungi and a decrease in the numbers of bacteria (17). 
Bioremediation processing defined as the use of microbes to detoxify or remove pollutants, which depend on upon microbial enzymatic activities to transform or degrade contaminants, has been greatly used in hydrocarbon mitigation $(18,19)$. Bioremediation is a natural procedure which relies on bacteria, fungi, and plants to alter contaminants as these organisms carry out their normal life functions. Metabolic practices of these organisms are skillful of using chemical contaminants as an energy source, rendering the contaminants harmless or less toxic products in most cases (20).

There are a number of publications on the bacterial biodegradation of the neonicotinoid group of pesticides, with the exclusion of imidacloprid, for which there are 12 published studies. A few research article have discussed the biodegradation of acetamiprid, thiacloprid and thiamethoxam, Many studies selected five photosensitive pesticides (carbendazim, acetochlor, simazine, EPTC, acetamiprid and chlorpyrifos) and six characteristic soil microbes (Bacillus subtilis, Pseudomonas fluorescens, Mycobacterium phlei, Fusarium oxysporum, Penicillium expansum, and Trichoderma harzianum) for conducting experiments (21). All the bacterial strains were subtle to the parent compound and its degradation produces. Microbial mediated bioremediation is of great significance because it promises a cheaper, simpler and more environmentally friendly method when compared to the more commonly active "muck, suck and truck" non-biological remedial methods, in which the contaminants are simply forced up or dug out and are then shipped away (22).

In agriculture, the increase of new plant protection formulations has long been a very active field of research as such problems associated with commercial pesticides must be overwhelmed (23). Researchers are presently designing formulations bacteria with enhanced features, that is, more soluble, slower releasing, and not prematurely degradable using the benefits of bacteria at scale. Though some of the above-mentioned microbes showed strong corresponding neonicotinoid insecticide degradation in nutritional broth by culture, the bioremediation of neonicotinoid insecticides in soil by culture of microbes in situ has rarely been reported.

Therefore, this paper highlights a significant potential uses of bacteria for the soil bioremediation. To isolate, characterize and identify a potential soil bacterium from contaminated soil and immobilization it with sodium alginate, then used it in two forms, liquid and capsulated for degradation potential of acetamiprid with three concentrations besides two soil types clay and sandy soil.

\section{Materials and Methods}

\section{Chemicals}

Analytical grade acetamiprid (purity, 99\%), purchased from Sigma-Aldrich (St. Louis, USA).The structure of formula of acetamiprid insecticide, was illustrated in Fig.1; (E)N1-[(6-chloro-3-pyridyl) methyl]-N2-cyano-N1-ethylacetamidine) while other organic 

solvents and chemicals were of analytical grade and purchased from standard commercial suppliers.

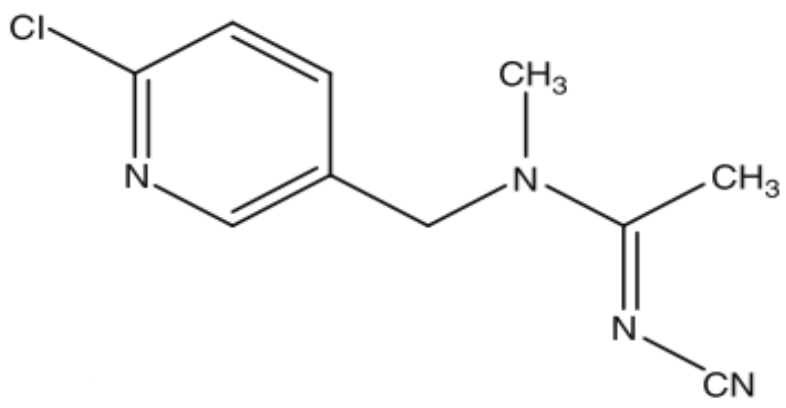

Fig.1. Chemical structure of acetamiprid pesticide

\section{Collection of soil samples:}

Rhizospheric soil samples were obtained from maize plant located of government of Giza $\left(30^{\circ} 01^{\prime} 13.6^{\prime \prime} \mathrm{N}-31^{\circ} 12^{\prime} 30.4^{\prime \prime} \mathrm{E}\right)$ treated with pesticides as an agriculture systematic practice. The root system were collected in aseptic bags and carried to the laboratory for further studies. Soil was collected from the surface $(0-15 \mathrm{~cm})$ of an upland soil at Soil, from Water and Environment Research Institute, Agriculture Research Center, Egypt. Physical and chemical properties are illustrated in Table 1. Soil samples were air-dried at room temperature, sieved at $1.0 \mathrm{~mm}$ to remove the plant material, soil macro fauna and stones, mixed thoroughly in a rotary cylinder and then stored at $4^{\circ} \mathrm{C}$ prior to use. Before using the soils were autoclaved $\left(121^{\circ} \mathrm{C}\right.$ at $\left.20 \mathrm{~min}\right)$. To prevent the photo degradation of the insecticides in soil, the pots were kept covered with a black polyethylene sheet.

Table1. Physiochemical properties of the soil under investigated:-

\begin{tabular}{|c|c|c|c|c|c|c|c|c|c|}
\hline \multicolumn{3}{|c|}{$\begin{array}{c}\text { Particle size } \\
\text { distribution }(\%)\end{array}$} & \multirow[t]{3}{*}{ Textural } & \multicolumn{6}{|c|}{ Chemical properties } \\
\hline Clay & Silt & Sand & & \multirow{2}{*}{$\begin{array}{l}\text { O.M. } \\
(\%)\end{array}$} & \multirow[t]{2}{*}{$\mathrm{EC} \mathrm{dS} / \mathrm{m}$} & \multicolumn{3}{|c|}{ Available (ppm) } & \multirow[t]{2}{*}{$\mathrm{pH}$} \\
\hline \multicolumn{3}{|c|}{$\%$} & & & & $\mathrm{~N}$ & $\mathrm{P}$ & $\mathrm{K}$ & \\
\hline 34.9 & 36.8 & 28.3 & Clay loam & 1.34 & 1.95 & 31.6 & 16.3 & 215.8 & 7.9 \\
\hline
\end{tabular}

Isolation, Purification and Morphological characteristic of rhizobacterial isolates:

Five grams of pesticide contaminated soil were added to $45 \mathrm{ml}$ sterilized water to have serial dilution up to $10^{7}$ fold. Dilutions from each sample were plated (in triplicate) on mineral salt medium (MSM) which contains $\mathrm{K}_{2} \mathrm{HPO} 4: 500 \mathrm{mg} ; \mathrm{KH}_{2} \mathrm{PO}$ : $250 \mathrm{mg}$; $\mathrm{NaCl}: 0.5 \mathrm{~g} ; \mathrm{NH}_{4} \mathrm{SO}_{4}: 230 \mathrm{mg} ; \mathrm{CaCl}_{2} .2 \mathrm{H}_{2} \mathrm{O}: 7.5 \mathrm{mg} ; \mathrm{MgSO}_{4} .7 \mathrm{H}_{2} \mathrm{O}: 100 \mathrm{mg}$; $\mathrm{MnSO}_{4} .7 \mathrm{H} 2 \mathrm{O}: 100 \mathrm{mg} ; \mathrm{FeCl}_{3}: 1 \mathrm{mg}$; Double Distilled Water: $1000 \mathrm{~mL}$ at $\mathrm{pH}=7$, under aseptic condition, Plates were incubated at $28 \pm 2{ }^{\circ} \mathrm{C}$ for $48 \mathrm{~h}$. The obtained microbial colonies were purified by transferred onto solid plates. Pure colonies were picked up in MSM slants, positively growing isolates were transferred in $35 \%$ glycerol (w/v) at- 
$80^{\circ} \mathrm{Cuntil}$ used it. Morphological characteristics of all isolates such as colony morphology (color, shape, surface) were studied According to "Bergey's Manual of Determinative Bacteriology" (24), grams stain was studied according to (25). The bacterial isolates were coded from (MSR: H1-H15).

\section{Screening of bacterial isolates for acetamiprid degradation}

Fifteen bacterial isolates were screened for their ability to degrade the acetamiprid when used as sole carbon, $5 \mathrm{ml}$ suspension bacteria from each isolate $\left(10^{7} \mathrm{cfu} / \mathrm{ml}\right)$ were transferred individually to $100 \mathrm{ml}$ conical flask, containing 50 salts medium (MSM) and $1 \%$ of acetamiprid was added as a sole carbon source and incubated at $30^{\circ} \mathrm{C}$ at 150 rpm for 5 days in orbital shaking incubator, non-inoculated flasks were kept as control afterwards, degradation of acetamiprid by selected isolates were evaluated in liquid culture by bacterial count by the plate count method according to (26).

\section{PCR Amplification of 16S rRNA Gene and Sequencing}

Active degradation bacteria isolate MSR H10 was identified by $16 \mathrm{~S}$ rRNA gene sequencing, using PCR master mix (Promega, Madison, WI, USA) with bacterial universal primer sets 27F and 1492R (27F: 5'- AGA GTT TGA TCC TGG CTC AG-3' and 1492R: 5'-TACGGYTACCTT GTTACGACT T-3'). Resolved 16S rRNA gene sequences were BLAST searched against the National Center for Biotechnology Information (NCBI) (http://www.ncbi.nlm.nih.gov) database (27). Multiple alignments of the nucleotide sequences were performed with the program MUSCLE (28). The phylogenetic tree was constructed by the Maximum Likelihood method (29), based on the Kimura 2-parameter model (30), with bootstrap analysis (1,000 replications) using the software MEGA (version 6) (31). The isolate was renamed Lysinobacillus macrolides strain MSR-H10. 


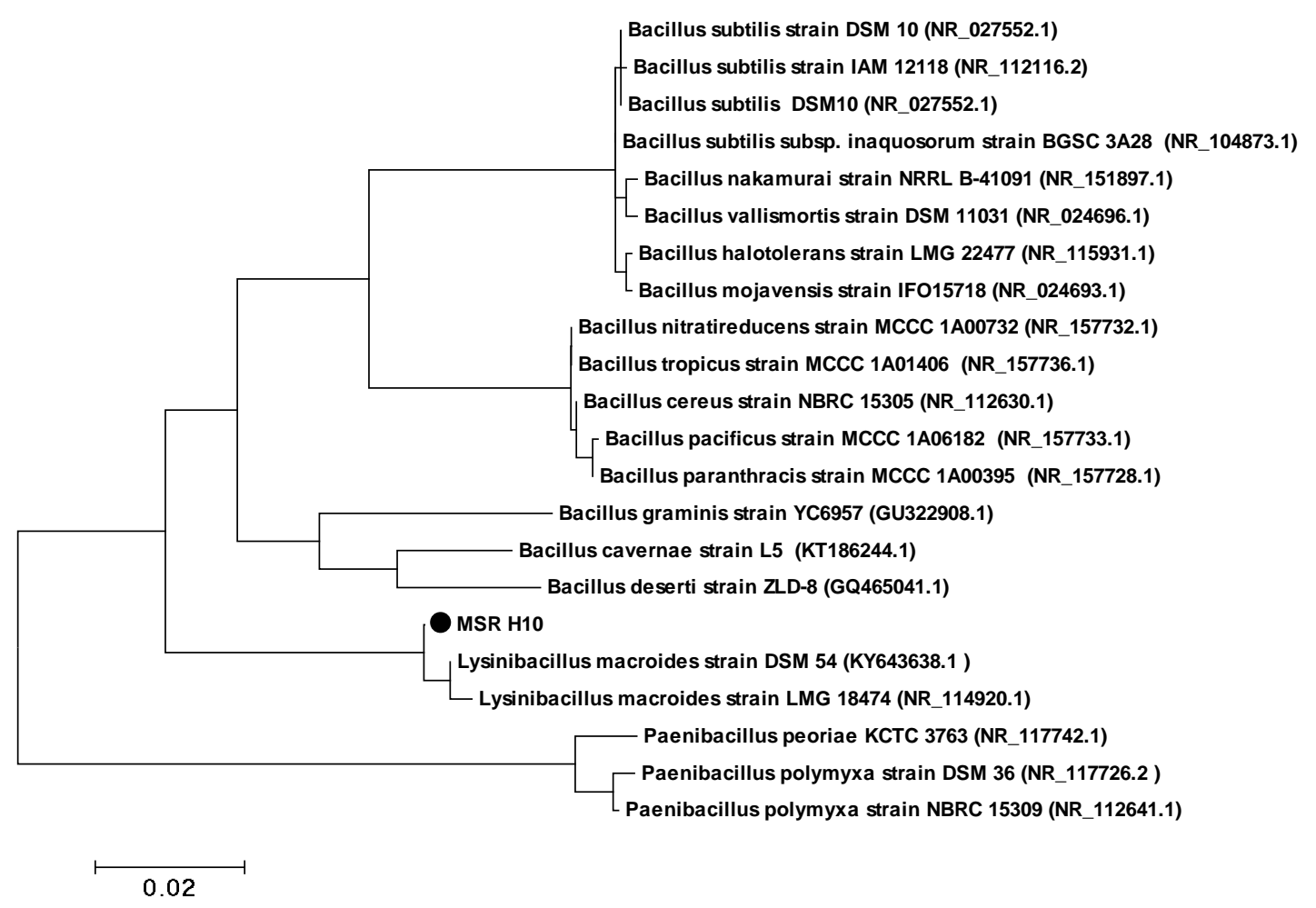

Fig. 2 Molecular Phylogenetic analysis by Maximum Likelihood method

The evolutionary history was inferred by using the Maximum Likelihood method based on the (32). The tree with the highest log likelihood (-4375.0812) is shown. Initial tree(s) for the heuristic search were obtained automatically by applying Neighbor-Join and BioNJ algorithms to a matrix of pairwise distances estimated using the Maximum Composite Likelihood (MCL) approach, and then selecting the topology with superior log likelihood value. The tree is drawn to scale, with branch lengths measured in the number of substitutions per site. The analysis involved 22 nucleotide sequences. All positions containing gaps and missing data were eliminated. There were a total of 1389 positions in the final dataset. Evolutionary analyses were conducted in MEGA6 (31).

\section{Capabilities L. macrolides strain $\mathrm{H10}$ for plant growth promoting activities.}

Indole acetic acid (IAA) production was determined according to protocol by (33). Catalase enzymes were estimated according to (34). Phosphate Solubilization was determined (35) where HCN production (36). The extracellular exopolysaccharide production (EPS) was determined according to (37) also Nitrogenase activity was estimated (38).

\section{Immobilized of L. macrolides strain MSR H10 by sodium alginate}

Bacteria strain was grown in $100 \mathrm{ml}$ nutrient broth media at $28^{\circ} \mathrm{C}$ for $48 \mathrm{~h}$. The cell was harvested at $\log$ phase $\left(10^{8} \mathrm{cfu} \mathrm{ml}^{-1}\right)$ by centrifugation $\left(4^{\circ} \mathrm{C}\right.$ at $\left.5000 \mathrm{~g}\right)$. Cell pellet was capsulated by mixed it with $2 \%$ of sodium alginate (ALGOGGL 3001, SG 30- 60, Degussa, France) and humic acid for $25 \mathrm{~min}$ at $350 \mathrm{rpm}$ on a magnetic stirrer (IKA® Modelo C-MAG) to form mixed homogeneously then introduced in a syringe and placed on the encapsulation device and extruded drop by drop through the needle $(1.55 \mathrm{~mm})$ by acting the syringe pump at the rate of $120 \mathrm{ml} / \mathrm{hr}$. Drops fell directly into 
$1.5 \% \mathrm{CaCl}_{2}$ solution for reticulation (39). The whole method was prepared under aseptic conditions in a laminar air flow hood. Capsules were stored in $0.85 \% \mathrm{NaCl}$ till used. Viability encapsulated beads was tested as described by (40).

Environmental factors (pH, temperature and agitation speed) affected on the growth of the most potent degrading bacterial $L$. macrolides

The effect of $\mathrm{pH}$, temperature and agitation speed on the growth of strain was studied; $100 \mathrm{ml}$ conical flasks containing $50 \mathrm{ml}$ MSM supplemented with $1 \%$ acetamiprid divided two groups the first group inoculated with $1 \mathrm{ml}$ from bacterial culture at $10^{7} \mathrm{cfu}$ $/ \mathrm{ml}$ while the other group inoculated with 2 beads of immobilized bacteria. To determine the $\mathrm{pH}$, flasks were approved out at $\mathrm{pH}$ via 6,7, 8 and 9. Wherase the effect of temperature, MSM medium at $\mathrm{pH} 7$ was incubated at via $25,30,35$ and $40^{\circ} \mathrm{C}$ at 150r/min for 10 days whereas, other flasks were incubated in orbital shaker at different agitation speed values via 0, 50,100 and 150rpm. All flasks were incubated for 10 days. The flasks without bacteria were kept as control. Three flasks were used for each experiment and we studied the effect of $\mathrm{pH}$, temperature and agitation speed on degradation on ACP by bacteria count.

\section{Biodegradation of acetamiprid by $L$. macrolides MSR H10 in soil}

\section{Inoculum preparation}

Lysinobacillus macrolides MSR H10 was grown in LB broth medium for 48 hours at $28^{\circ} \mathrm{C}$ to exponential phase $\left(6 \times 10^{7} \mathrm{cfu} \mathrm{ml}^{-1}\right)$, Two forms of bacterial inoculums were used, either in capsules ( 5 capsules for each pot) or liquid culture $\left(1 \mathrm{mLx} 10^{7} \mathrm{cfu}^{-1}\right)$.

\section{Soil treatments}

A plastic pot $15 \mathrm{~cm}$ in diameter and $13 \mathrm{~cm}$ depth were prepared and received with $1500 \mathrm{~g}$ dried soils to evaluate the bioremediation in contaminated soil. About $400 \mathrm{ml}$ distilled water was added and the final moisture content of the soil was approximately $60 \%$ of the maximum water-holding capacity (WHC). An aqueous solution of acetamiprid was added into soil to make the final concentrations of 1,5 and $10 \mathrm{mg} \mathrm{kg}^{-1}$ dried soil in soil afterward one $\mathrm{mL}$ of inoculum was added to every pot. During incubation period certain amount of distilled water was added to keep the WHC. The control was without bacteria ( soil amended with distilled sterile water) in order to obtain the same final moisture content of the soil was approximately $60 \%$ soil WHC to allow the comparison of the microbial abundance in the absence/presence of acetamiprid insecticide. 


\section{Analytical procedure:}

\section{Extraction of acetamiprid}

During the experiment, samples (50g) were collected periodically at 1, 7, 14, 21 and 28 days intervals of time for estimation of pesticide degradation. The concentration of acetamiprid was estimated by HPLC for each time we transferred into $250 \mathrm{ml}$ centrifuge funnel. Afterwards, added $40 \mathrm{ml}$ dichloromethane to $40 \mathrm{ml}$ of sodium chloride solution (20\%). Sample was vigorously shaken for one hour and allowed to stand until separation of layers. The dichloromethane layer was collected in a clean bottle and the aqueous layer was re-extracted twice with $20 \mathrm{ml}$ dichloromethane. Dichloromethane fractions were recombined in a clean bottle and dried up by passing through anhydrous sodium sulphate on a filter paper. The solvent was concentrated to near dryness and the residues were re-constituted in $1 \mathrm{ml}$ dichloromethane and stored in the refrigerator at $5^{\circ} \mathrm{C}$ for chromatographic determination by HPLC (41).

\section{Chromatographic determination of acetamiprid residues}

The concentrations of acetamiprid were determined using an Agilent HPLC 1260 infinity series (Agilent technologies) equipped with a quaternary pump, a variable wavelength diode array detector (DAD), an auto sampler with an electric sample valve. The column was Nucleosil C18 (30 cm x $4.6 \mathrm{~mm}$ (i.d) x $5 \mu \mathrm{m}$ film thickness). The mobile phase was 56/35 (V/V) mixture of HPLC grade acetonitrile /water. The wavelength was $220 \mathrm{~nm}$ and the mobile phase flow rate was $0.8 \mathrm{ml} / \mathrm{min}$. The retention time of acetamiprid under these conditions was $20 \mathrm{ul}$ and the injection volume was 2.6 $\mu \mathrm{L}$ under these conditions.

\section{Statistical analysis}

This work was randomized block design. Least significant difference test was used to compare means using the statistical analysis software; CoStat (CoHort Software, U.S.A) version 6.4 . The values 8 of probability $\mathrm{p} \leq 0.05$ were considered statistically significant. Based on the least significant difference test.

\section{Results and Discussion}

\section{Screening of bacterial isolates for acetamiprid (AAP) degradation}

The ability of 15 isolates to degrade AAP was chiefly examined in MSM broth media containing $1 \%$ acetamiprid incubated at $30^{\circ} \mathrm{C}$.Only acetampirid tolerant bacteria will survive in the minimal broth and a Log of bacterial count number $(\mathrm{CFU} / \mathrm{ml})$ were determined as shown in Fig.3 AAP is a member of the neonicotinoid group of insecticides generally used against wide range of insect pests; AAP is used usually in crop protection (42 and 43).Consequently, it is probable that several bacteria adapted to this acetamiprid-contaminated environment. Many of these bacteria used the contaminant as the sole source of carbon and energy. Only ten bacterial were capable 
to grow display good growth in MSM media and degradation of AAP. No. H10 and $\mathrm{H} 2$ recorded highest growth 9.0 and $8.6 \mathrm{CFU} / \mathrm{ml}$ while isolate No. H3, H4, H8, H11 and H12 can't able to grow and degradation the AAP in MSM media. In this concern, similar results obtained from (44) strains from Ochrobactrum genus have been reported to degrade various xenobiotics such as vinyl chloride, dimethyl formamide (45), methyl parathion (46). The bacterial isolate No.H10 appeared brownish in color with powdery texture after incubation period also. Therefore, it is selected to identify by $16 \mathrm{~S} r$ RNA.

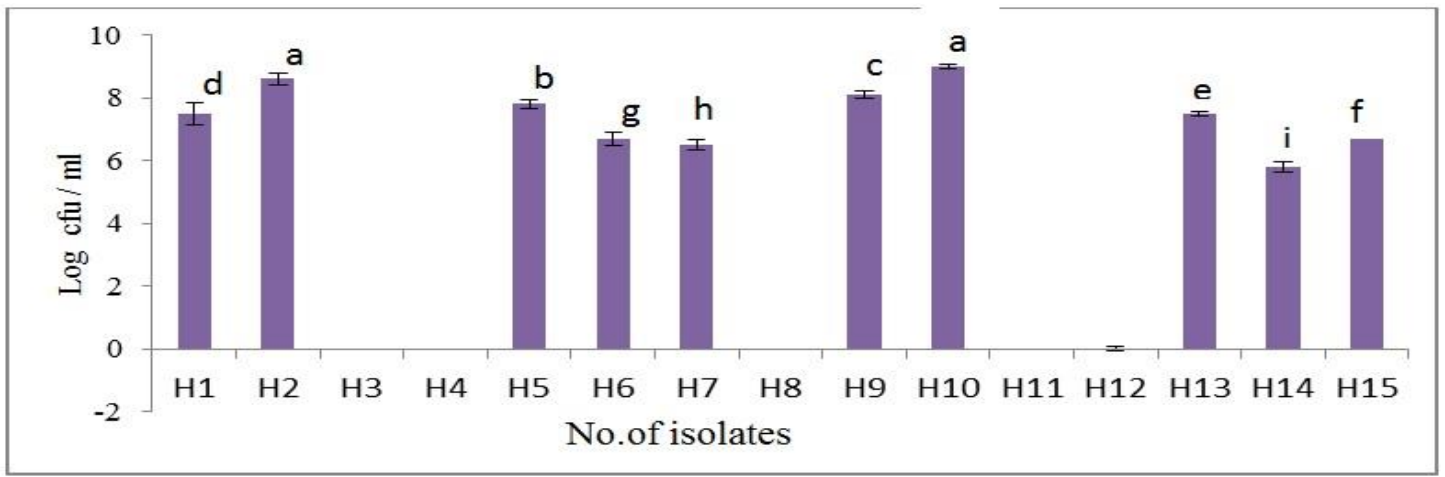

Fig.3. Bacterial count ( $\log \mathrm{cfu} / \mathrm{ml})$ grown on MSM supplemented with $1 \%$ of acetamprid.

\section{Identification and biochemical characterization of the best performing isolates MSR H10.}

Based on the 16S rRNA, the H10 isolate was identified as Lysinobacillus macrolides with a close relative to Lysinobacillus macrolides strain DSM54 and LMG8474 with 99\% sequence match Fig.2. MSR H10 was evaluated for the plant growth promoting rhizobacteria (Table 2). The strain was found to be a Gram-positive, rod shape, produces IAA, positive to catalase test, as well solubilize the tricalcium phosphate, production the hydrogen cyanide on Kings B agar medium amended with glycine, it could also producing exopolysaccharides (EPS), and able to fix Nitrogen in media, this results are in harmony with previously reported results of the same species (47) and (48). After soil or foliar application, Thia- accelerates the improvement of PGPR such as B. pumilus, B. subtilis (49). It can also improve production of EPS and other substances by the PGPR P. putida, Klebsiella sp., Rhizobium sp., and Bradyrhizobium sp. (50). Enhanced production of these substances is useful for the growth and vigor of certain plants. 
Table 2. physio-biochemical characteristics and plant growth promoting capabilities of L. macrolides MSR H10.

\begin{tabular}{|c|c|}
\hline Characteristics & L. macrolides strain MSR H10 \\
\hline Cell shape & Rod shaped \\
\hline Gram-staining & + \\
\hline Motility & Motile \\
\hline Colony shape & Circular- convex \\
\hline indol acetic acid (IAA) & + \\
\hline Catalase Test & + \\
\hline Phosphate solubilization & + \\
\hline HCN & + \\
\hline EPS production & + \\
\hline Nitrogenase activity & + \\
\hline
\end{tabular}

Optimization of the Environmental Conditions on the growth of the most potent degrading bacterial Lysinobacillus macrolides MSR H10

Temperature, $\mathrm{pH}$, oxygen, substrate concentration, etc. could affect the degradation (51). Microorganisms can be isolated from almost any environmental conditions. Microbes will adjust and grow at subzero temperatures, as well as extreme heat, desert conditions. In this study, the optimum $\mathrm{pH}$, temperature and agitation speed value for degradation APP was studied by inoculation bacteria in two types in MSM media

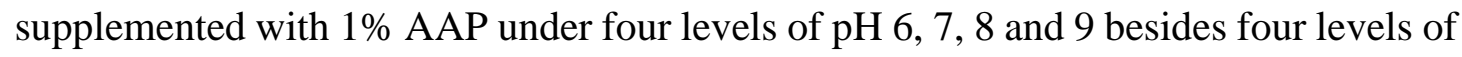
temperature $25,30,35$ and $40^{\circ} \mathrm{C}$ while the agitation speed under $0,50,150$ and $250 \mathrm{rpm}$ Fig.4 ( $\mathrm{a}, \mathrm{b}$ and c). Bacteria needed a suitable temperature, $\mathrm{pH}$ and agitation speed value for growth and degradation the AAP. L. macrolides in two types can able to grow at different value of $\mathrm{pH}$, temperature and agitation speed, the growth is decreased under $\mathrm{pH}$ value 9 and $40^{\circ} \mathrm{C}$ under $50 \mathrm{rpm}$ whereas the optimum growth for degradation AAP were $\mathrm{pH} 7$ at $30^{\circ} \mathrm{C}$ under $200 \mathrm{rpm}$. Immobilized bacteria with sodium alginate recorded highest value for growth compared to free culture, the maximum microbial population were $9.34 \mathrm{cfu} / \mathrm{ml}$ at $\mathrm{pH}(7), 9.4 \mathrm{cfu} / \mathrm{ml}$ under $30^{\circ} \mathrm{C}, 10.0 \mathrm{cfu} / \mathrm{ml}$ under $250 \mathrm{rpm}$ respecatavely.Temperature,humidity and agitation were the most important factors, which affected the growth and degradation (52). (53) found that several factors including $\mathrm{pH}$ and temperature affected degradation of fenitrothion-contaminated soil. (54) confirmed the effects of different temperatures $\left(20^{\circ} \mathrm{C}, 25^{\circ} \mathrm{C}, 30^{\circ} \mathrm{C}, 35^{\circ} \mathrm{C}\right.$ and $\left.40^{\circ} \mathrm{C}\right)$ and $\mathrm{pH}(5,6,7,8$ and 9$)$ on the imidacloprid biodegradation rate, and he found that, the optimum conditions for degradation were a $\mathrm{pH}$ of 8 and temperature of $30^{\circ} \mathrm{C}$. 

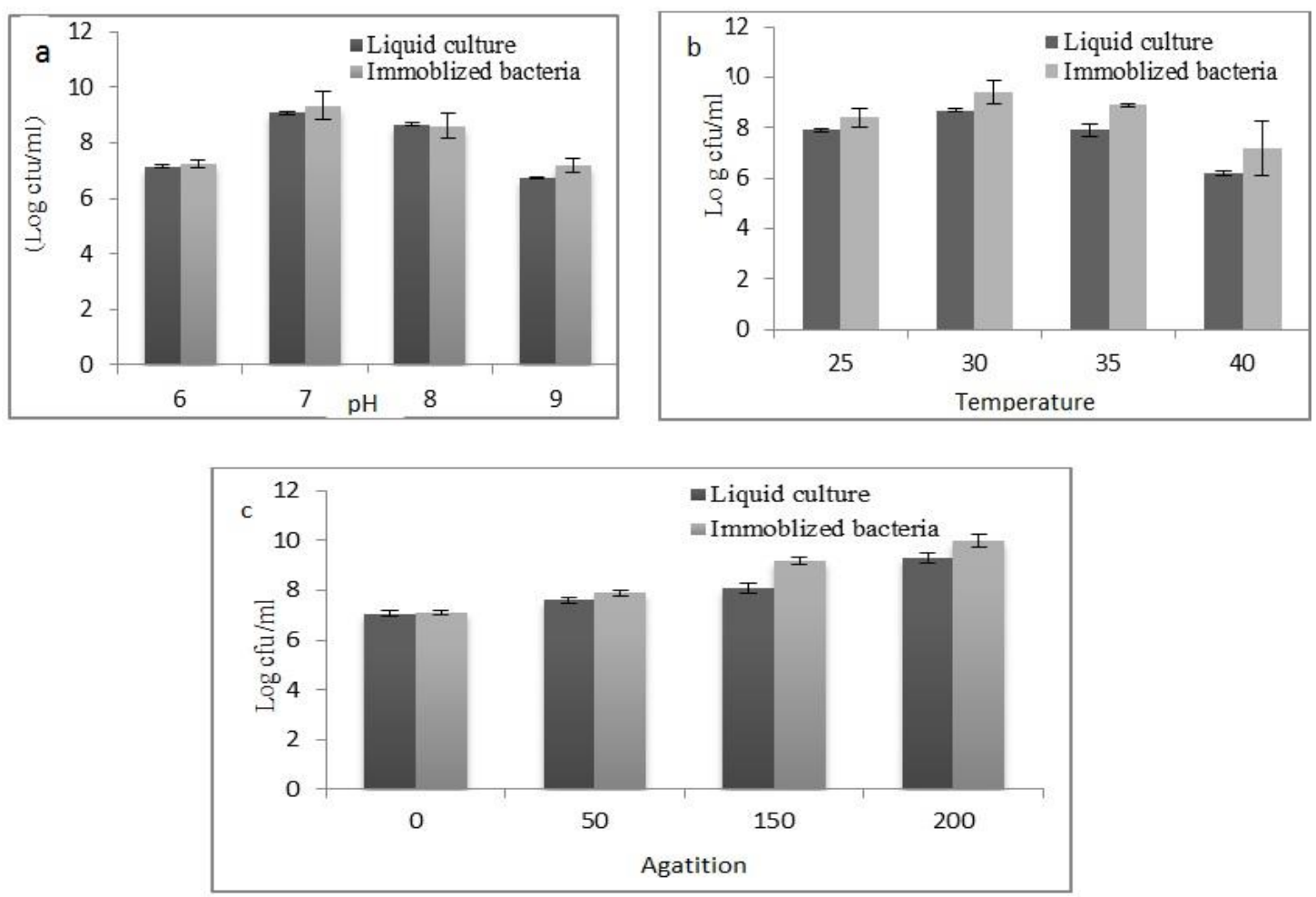

Fig. 4. Effect of $\mathrm{pH}$ (a), temperature (b) and agitation (c) on the growth of the most potent degrading bacterial Lysinobacillus macrolides MSR H10; values are the means of three replicates with standard deviation.

\section{Biodegradation potential of acetamiprid (AAP) soils by $L$. macrolides}

Biodegradation rate of acetamiprid at different concentrations $\left(1,5\right.$ and $\left.10 \mathrm{mg} \mathrm{L}^{-1}\right)$ by two forms of bacteria was studied in two types of polluted soils (sandy and clay) under $30^{\circ} \mathrm{C}$ and $\mathrm{pH} 7$ after 1,7,14,21 and 28 days by HPLC are illustrated Fig. (5, 6 and 7) respectively. There was an initial phase of slower degradation, which was longer at high concentrations, polluted sandy or clay soil with three concentration AAP supplemented with bacteria showed a significant higher AAP degradation rate compared with polluted soil untreated with bacteria. There was also little degradation of AAP at all concentrations in the untreated soil during the 28 day of incubation period. AAP concentration $1 \mathrm{mg} / \mathrm{L}$ (Fig.5 a and b) the hydrolysis percentages recoded 16 and 19\% respectively in untreated soil, while were $92 \%$ with treated sandy soil by liquid culture and zero with sandy soil treated with capsulated bacteria on the other hand the hydrolysis percentages in clay soil recorded $18 \%$ with liquid culture and $94 \%$ with capsulated bacteria respectively. After 28 days the hydrolysis percentages recoded highest degradation compared with other periods in all concentration. Under AAP concentration $5 \mathrm{mg} / \mathrm{L}$ (Fig.6 a and b) the hydrolysis percentages in sandy soil recorded $97.2 \%$ with liquid culture compared to $96.8 \%$ with capsulated soil whereas in clay soil the hydrolysis percentages recorded zero with two forms bacteria after 28 days from incubation period. The concentration percentage was $1.2 \mathrm{ppm}$ in clay soil treated with capsulated bacteria compared to untreated soil recorded 0.93 ppm AAP after 21 days 
from incubation. At concentration $10 \mathrm{mg} / \mathrm{L}$ (Fig. $7 \mathrm{a}$ and b) AAP the degradations rates reached $89.1 \%$ and $98.8 \%$ respectively compared to control $14.2 \%$ in sandy soil while were $98.9 \%$ and $98.8 \%$ respectively in clay soil after 28 days from incubation period compared to control compared to control $12.9 \%$. Generally, the degradation of AAP was achieved higher at concentration $5 \mathrm{mg} / \mathrm{L}$ after 21 days in clay soil treated with two forms of bacterial, while at concentration $10 \mathrm{mg} / \mathrm{L}$ the degration AAP was achieved higher after 28 days in sandy and clay soil, it was noteworthy that this particular strain could tolerate and proficiently degrade acetamiprid up to the concentration, as high as $10 \mathrm{mg} / \mathrm{L}$. The loss of AAP in untreated clay soil was $12.9 \%$ and this may be due to evaporation, drift or leaching, while the loss win soil treated with capsulated soil was $98.8 \%$. These conclusions indicated that increased acetamiprid concentration had a marked effect on degradation performance of strain Lysinobacillus macrolides, but did not lead to complete inhibition. These results showed that strain L. macrolides were responsible for acetamiprid degradation. It was detected that, with an increase in the concentration of the acetamiprid, the degradation potential of the isolate decreases and is completely inhibited at a concentration of $10 \mathrm{mg} / \mathrm{L}$ of AAP, Moreover, (55) demonstrated that Strain D-12 was able to completely degrade acetamiprid with initial concentrations of $0-3000 \mathrm{mg} / \mathrm{L}$ within $48 \mathrm{~h}$. bacterial strain was able to utilize acetamiprid as a sole carbon, nitrogen and energy source, albeit with low growth rates (56). The bacterial was able to degrade the substrate completely up to $10 \mathrm{mg} / \mathrm{L}$ of AAP in soil. (57). They found that acetamiprid could be transformed with a maximum specific degradation rate, half-saturation constant and inhibit constant of $1.775 / 36 \mathrm{~h}$, $175.3 \mathrm{mg} \mathrm{L}^{-1}$ and $396.5 \mathrm{mg} \mathrm{L}^{-1}$, respectively, illustrating that the degradation rate of acetamiprid was restrained at high concentration. Similarly, Neonicotinoid metabolites can vary usually depending on the chemical structure of the pesticide and the catabolic activity of a degrading microorganism under a specific set of environmental conditions (58).
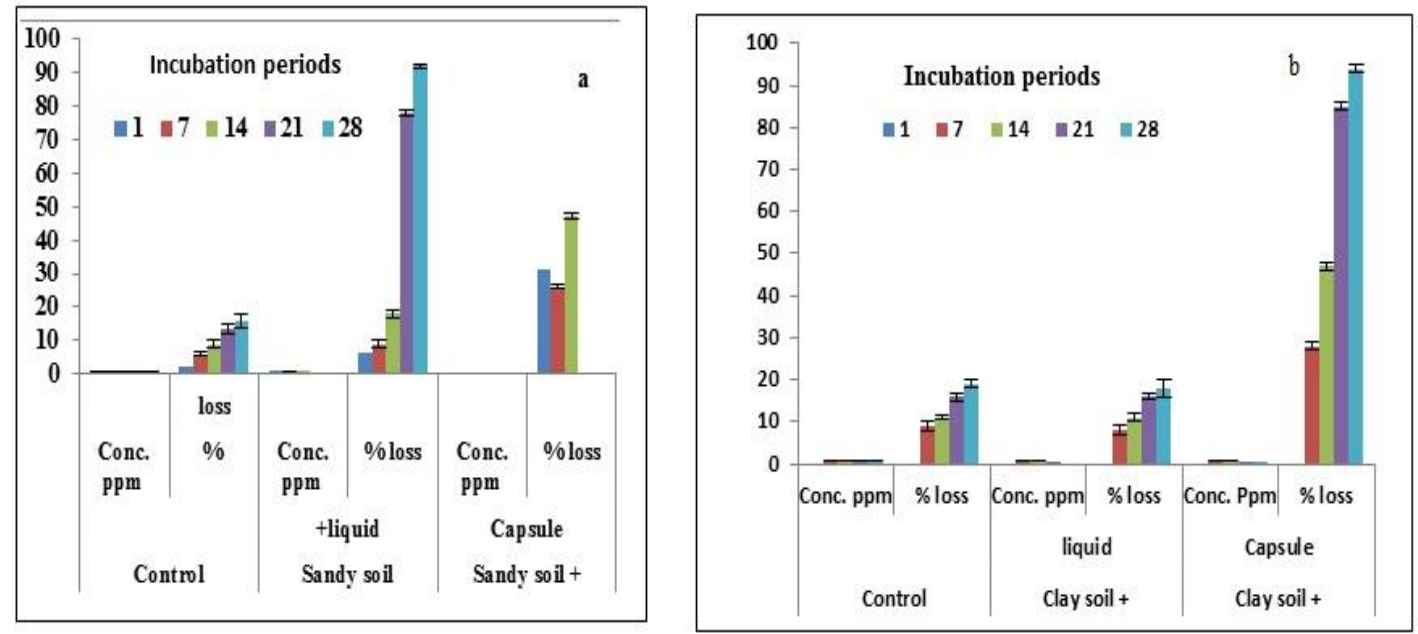

Fig.5. Degradation of AAP at $1 \mathrm{mg} \mathrm{L}^{-1}$ by strain L. macrolides in sandy (a) and clay (b) soil after 1, 7, 14, 21 and 28 days from incubation periods. Values are the means of three replicates with standard deviation 
ISSN 2537_0715

IJSRSD (2020): Volume 3, Issue 3, December 2020

Received: August 2020, Accepted: October 2020
International Journal of Scientific

Research and Sustainable Development
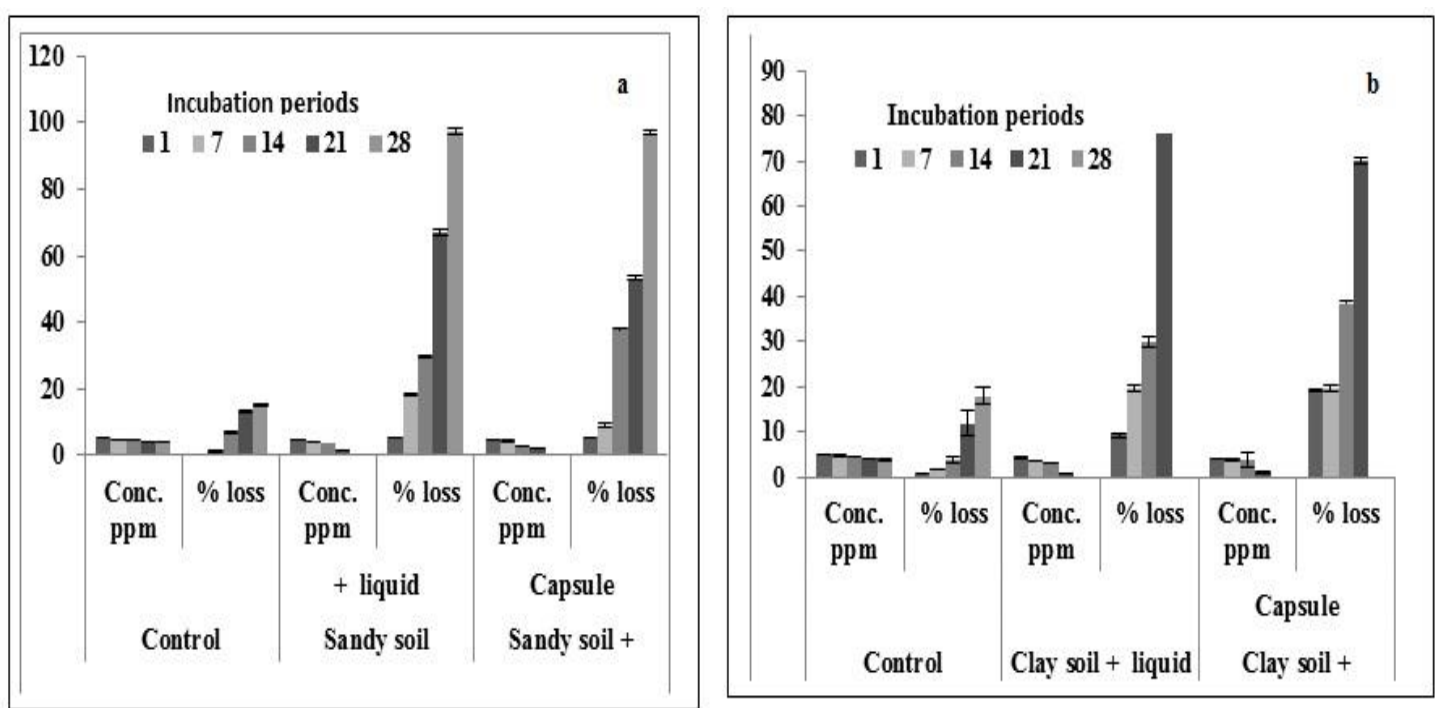

Fig.6 : Degradation of AAP at $5 \mathrm{mg} \mathrm{L-1}$ by strain L. macrolides in sandy (A) and clay (B) soil after 1, 7, 14, 21 and 28 days from incubation periods. Values are the means of three replicates with standard deviation.
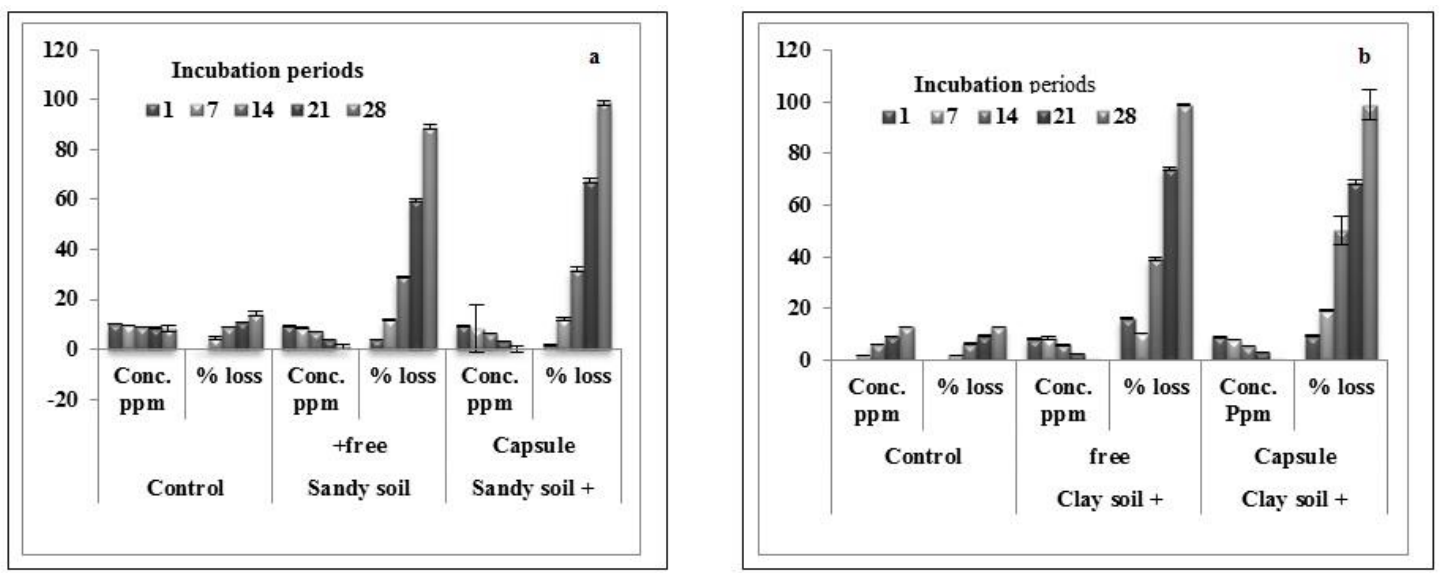

Fig.7. Degradation of AAP at $10 \mathrm{mg} \mathrm{L-1}$ by strain L. macrolides in sandy (A) and clay (b) soil after 1,7,14,21 and 28 days from incubation periods. ; Values are the means of three replicates with standard deviation. 


\section{Conclusions}

In the present study, we isolated 15 isolates, screening of potential acetamiprid degradation. PCR amplification followed by of $16 \mathrm{~S}$ rRNA gene sequencing were used to identify most performing strain $\mathrm{H} 10$ as L. macrolides MSR H10. Immobilization of the bacteria in a solid matrix is a benefit ended the free culture and can be used, giving an enhanced costly appeared to be highly efficient in degrading acetampired in soil. Temperature, $\mathrm{pH}$, and agitation speed play key roles in determining the rate of acetampired degradation and this strain could be a significant potential using for crackdown of acetamiprid-contaminated soil. Moreover, the immobilized strain was able to degrade the acetamiprid completely up to $10 \mathrm{mg} / \mathrm{L}$ of AAP in soil after 21 days from incubation periods.

\section{References}

1. Bass, C., I. Denholm, M.S. Williamson, R. Nauen, .2015. The global status of insect resistance to neonicotinoid insecticides, Pestic. Biochem. Physiol. 121. 78-87.

2. Gill, R.J., O. Ramos-Rodriguez, N.E. 2012. Raine, Combined pesticide exposure severely affects individual-and colony-level traits in bees, Nature 491. 10119.

3. Gill, B., W. Emily, P. Abbe, D.G. Michael, C. Nora .2017. Neonicotinoids act like endocrine disrupting chemicals in newly-emerged bees and winter bees, Nature 7 10797.

4. Hladik, M., W. Kolpin, K. Kuivila. 2014. Widespread occurrence of neonicotinoid insecticides in streams in a high corn and soybean producing region, USA, Environ. Pollut.193. 189-196.

5. Morrissey, C.A., P. Mineau, J.H. Devries, F. Sanchez-Bayo, M. Liess, M.C. Cavallaro. 2015. Neonicotinoid contamination of global surface waters and associated risk to aquatic invertebrates: a review, Environ. Int. 74. 291-303.

6. Shivanandappa T, Y. Rajashekar. 2014. Mode of action of plant derieved natural insecticides. In: Singh D (ed.). Advances in Plant Biopesticides. New Delhi, India: Springer, 317-22.

7. Gibbons, B., C. Morrissey, P. Mineau.2015. A review of the direct and indirect effects of neonicotinoids and fipronil on vertebrate wildlife, Environ. Sci. Pollut. Res. Int. 22. 103-11.

8. Henry M., M. Béguin ., F. Requier., O. Rollin., J.F. Odoux., P. Aupinel., S.J. Aptel Tchamitchian., and A. Decourtye. 2012 .A common pesticide decreases foraging success and survival in honey bees, Science 336. 348-350.

9. Whitehorn P.R., S. O’Connor., F.L Wackers., D. Goulson. 2012. Neonicotinoid pesticide reduces bumble bee colony growth and queen production, Science 336. 351-352.

10. Pramanik, S.K., J, Bhattacharyya., S. Dutta., P.K Dey., A .Bhattacharyya, et al. 2006. Persistence of acetamiprid in/on mustard (Brassica juncea L.). Bull Environ Contam Toxicol 76: 356-360. 
International Journal of Scientific

Research and Sustainable Development

11. Sanyal D., D. Chakma., S. Alam .2008. Persistence of a neonicotinoid insecticide, acetamiprid on chili (Capsicum annum L.). Bull Environ Contam Toxicol 81: 365368.

12. Suman Gupta and V. T. Gajbhiye. 2007. Persistence of Acetamiprid in Soil. Bulletin of Environmental Contamination and Toxicology. Tec;39:843-907.

13. Belal E.B., N.A Zidan., H.A Mahmoud., F.I. Eissa .2008. Bioremediation ofpesticides - contaminated soils. J. Agric. Res. Kafrelsheikh Univ. 34:588- 608.

14. Vidali .2001.Bioremediation. An overview Pure Appl. Chem., Vol. 73, No. 7, pp. $1163-1172$.

15. Chi-Chu L. 2010. "Effect of pesticides on soil microbial community". Journal of Environmental Science and Health Part B 45.5: 348-359.

16. Mohammed Farhan Al-Helali1., Amani Ahmed Fadhel Qardash, Abdurahman Ali Mohammed Thabet., Muath Abdumajeed Ba'abad and Wadhah Hassan Edrees1. 2019. Study the Effects of Chemical Pesticides on Soil Bacterial Community on Khat Agriculture in Dhala Governorate, Yemen Clinical Biotechnology and Microbiology 3.2 : 599-604.

17. Jerzy D, and J.M Bollag. 2001. "Use of Enzymes in Bioremediation, In: Pesticides Biotransformation in Plants and Microorganisms: Similaritiesand Divergences". American Chemical Society, Washington, D C ; 182-193.

18. Margesin, R., M. Hammerle,. and D. Tscherko. 2007. Microbial activity and community composition during bioremediation of diesel-oil contaminated soil: effects of hydrocarbon concentration, fertilizers and incubation time. Microb. Ecol., 55:259-269.

19. Wolicka, D., A. Suszek., A. Borkowski. and A. Bielecka. 2009. Application of aerobic microorganisms in bioremediation in situ of soil contaminated by petroleum products . Bioresour. Technol., 100:3221-3227.

20. Biobasics: The Science and the Issues. 9 Feb., 2006. Biotechnol. Bioeng. 14: 309318.

21. Soyeb A., M. Suchanda., G.K Ghosh., P.K Biswas., M.C Kundu. 2016. Effect of pesticides on mineral nitrogen content and soil microbial population in a lateritic soil of. West Bengal 6(3):27-32.

22. Lovley, D. R. 2003. Cleaning up with genomics: applying molecular biology to bioremediation. Nat. Rev. Microbiol. 1, 35-44. doi: 10.1038/nrmicro731.

23. Kah M. 2015. Nanopesticides and nanofertilizers: emerging contaminants or opportunities for risk mitigation? Front. Chem 3:1-6. 10.3389/fchem.2015.00064.

24. Holt, J.G., N.R. Krieg., P.H.A. Sneath., J.T. Staley and S.T Williams .1994.In Bergy's Manual of Determinative Bacteriology, ninth ed., Williams and Wilkins Pub, MD, USA.

25. Hegazi, N. A and S. Niemela. 1976. A note on the estimation of Azotobacter densities by filter technique. 1. Appl. Bacteriol., 41, 311-323. 1. 33: 1870- 1874. doi: 10.1093/molbev/msw054.

26. Khalida, K. Naeem., M., A. M. Javed and M.Asif. 2006. Extraction and Charcterization of oil degrading bacteria. J.Appl. Sci., 6:2302-2306. 
27. Altschul, S.F., T.L. Madden., J. Zhang and W. Miller .1997. Gapped BLAST and PSI-BLAST: A new generation of protein database search programs.Nucleic Acids Res., 25: 3389-3402. doi:10.1093/nar/25.17.3389.

28. Edgar, R. C. 2004. MUSCLE: multiple sequence alignment with high accuracy and high throughput. Nucleic Acids Res. 32: 1792-1797. doi: 10.1093/ nar/gkh340.

29. Saitou, N. and Nei, M. 1987.The neighbor-joining method: A new method for reconstructing phylogenetic trees. Molecular Biology and Evolution, 4: 406-425.

30. Kimura, M. 1980. A simple method for estimating evolutionary rates of base substitutions through comparative studies of nucleotide sequences. J. Mol. Evol. 16: 111-120. doi: 10.1007/BF01731581.

31. Kumar, S.,G. Stecher. And K. Tamura .2016. MEGA7: molecular evolutionary genetics analysis version 7.0 for bigger datasets. Mol. Biol. Evo.

32. Tamura K and Nei M. 1993. Estimation of the number of nucleotide substitutions in the control region of mitochondrial DNA in humans and chimpanzees. Mol Biol Evol. 10:512-526.

33. Adesemoye, A. O., H.A. Torbert., \& J.W.Kloepper. 2009. Plant Growth- Promoting Rhizobacteria Allow Reduced Application Rates of Chemical Fertilizers. Microbial Ecology, 58, 921-929.

34. Schaad N.W.1992. Laboratory Guide for Identification of Plant Pathogenic Bacteria, 2nd Edn, International Book Distributing Co,Lucknow. 44-58.

35. Pikovskaya R.I. 1948. Mobilization of phosphorous in soil in connection with vital activity of some microbial species. Microbiologica.; 17: 362-370.

36. Bakker, A. W. and B. Schipperes, (1987). Microbial cyanide production in the rhizosphere in relation to potato yield reduction and Pseudomoas spp. - mediated plant growth stimulation. Soil Biol. Biochem. 19: 451 - 457.

37. Damery, J.T and M. Alexander. 1969. Physiological differences between effective and ineffective strains of Rhizobium. Soil. Sci.103: 209-215.

38. Cappuccino, J.G and N. Sherman. 2002. Microbiology: a laboratory manual (8th edition,) Pearson. ISBN-13:978-0805325782.

39. Ivanova E., E.Teunou.,D. Poncelet D. 2005. Alginate based macrocapsules as inoculants carriers for production of nitrogen bio fertilizers. Proc. Balk. Sic. Conf. Biol.; 90-108.

40. Maged M. Saad., H. A. Abo-Koura., K. M. Abd El-Latif and M. M. Aly. 2020. Application of alginate bead encapsulated $\mathrm{N}_{2}$-fixing bacteria is improving wheat yield under drought stress. Plant Archives Vol. 20, No. 1, pp. 1735-1747. eISSN:2581-6063 (online), ISSN:0972-5210.

41. Suman Gupta and E V. T. Gajbhiye .2007. Persistence of Acetamiprid in Soil. Bulletin of Environmental Contamination and Toxicology. Published online: 31 May 2007.

42. Fitzgerald J. 2004. Laboratory bioassays and field evaluation of insecticides for the control of Anthonomus rubi, Lygus rugulipennis and Chaetosiphon fragaefolii, and effects on beneficial species in UK strawberry production, Crop Prot 23: 801-809. 
International Journal of Scientific

Research and Sustainable Development

43. Yao X.H and Min H (2006a) Isolation, characterization and phylogenetic analysis of a bacterial strain capable of degrading acetamiprid. J Environ Sci-China 18: 141146.

44. Danko, A.S., M.Z Luo. C.E, Bagwell., R.L Brigmon., D.L Freedman, et al. 2004. Involvement of Linear Plasmids in Aerobic Biodegradation of Vinyl Chloride Appl Environ Microbiol 70: 6092-6097.

45. Veeranagouda Y., P.V.E Paul and P Gorla . 2006. Complete mineralisation of dimethylformamide by Ochrobactrum sp. DGVK1 isolated from the soil samples collected from the coalmine leftovers. Appl Microbiol Biotechnol 71: 369-375.

46. Qiu X.H., W.Q Bai., Q.Z Zhong., M. Li., M.Q .He and et al. 2006. Isolation and characterization of a bacterial strain of the genus Ochrobactrum with methyl parathion mineralizing activity. J Appl Microbiol 101: 986-994.

47. Chunjie, Z.h.u., S.u.n Guoping., Xingjuan Chen., Jun Guo and X.u Meiying .2014. Lysinibacillus varians sp. nov., an endosporeforming bacterium with a filament-torod cell cycle. International Journal of Systematic and Evolutionary Microbiology , 64, 3644-3649. DOI 10.1099/ijs.0.068320-0

48. Sang-Mo Kang, Abdul Latif Khan, Muhammad Waqas, Sajjad Asaf, Ko-Eun Lee, Yeon-Gyeong Park, Ah-Yeong Kim, Muhammad Aaqil Khan, Young-Hyun You \& In-Jung Lee .2019. Integrated phytohormone production by the plant growthpromoting rhizobacterium Bacillus tequilensis SSB07 induced thermo tolerance in soybean Journal of Plant Interactions, vol. 14, No. 1, 416-423 https://doi.org/10.1080/17429145.2019.1640294.

49. Myresiotis, C., Z.Vryzas., E. Papadopoulou-Mourkidou .2011. Biodegradation of soil-applied pesticides by selected strains of plant growth-promoting rhizobacteria (PGPR) and their effects on natural insecticides. In: Singh D (ed.). Advances in Plant Biopesticides. New Delhi, India: Springer, 2014, 317-22.

50. Ahemad, M., M.S Khan .2011a. Effects of insecticides on plant-growth promoting activities of phosphate solubilizing rhizobacterium bacterial growth. Biodegradation 23:297-310.

51. Bhattacharya M.,D. Biswas., S. Sana., S. Datta .2014. Utilization of waste engine oil by Ochrobactrum pseudintermedium strain $\mathrm{C} 1$ that secretes an exopolysaccharide as a bioemulsifier. Biocatal Agric Biotechnol 3:167-176.

52. Arbeli, Z.; C.L Fuentes. 2010. Microbial Degradation of Pesticides in Tropical Soils. Soil Biol. Agric. Trop., 21, 251-274. [CrossRef].

53. Hong Q, Z. Zhang., Y Hong and S. Li. 2007.A microcosm study on bioremediation of fenitrothion-contaminated soil using Burkholderia sp. FDS-1. Internat. Biodeter.\& Biod. 59: 55-61.

54. Hu G., Y. Zhao., B. Liu et al.2013.Isolation of an indigenous imidacloprid degrading bacterium and imidacloprid bioremediation under simulated in situ and ex situ Conditions. J MicrobiolBiotechn;23:1617-26.

55. Guangli Wang., Xiao Chen., Wenlong Yue., Hui Zhang., Feng Li., Minghua Xiong .2013. Microbial Degradation of Acetamiprid by Ochrobactrum sp. D-12 Isolated from Contaminated Soil. PLOS ONE | Volume 8 | Issue 12 | e82603. 
56. Wang, G., W. Yue, Y. Liu., F. Li., M. Xiong and H. Zhang., Bioresour. Technol. 2013. Microbial degradation of acetamiprid by Ochrobactrum sp. D-12 isolated from contaminated soil. Pols 8(12): 359-368.

57. Chen S., Y.H Dong., C. Chang et al. 2013. Characterization of a novel cyfluthrindegrading bacterial strain Brevibacterium aureum and its biochemical degradation pathway. Bioresource Technol;132: 16-23.

58. Hussain S., T. Siddique., M. Arshad et al. 2009. Bioremediation and phytoremediation of pesticides: recent advances. Crit Rev Env Sci Tec;39:843-907.

$$
\text { الملخص العربى }
$$

التكسير الحيوي لمبيد الاسيتاميريد باستخدام بكتيريا Lysinobacillus macrolides MSR-H10 في

$$
\text { التربه في صوره سائله او مغلفه }
$$

$$
\text { 1-ابراهيم متولي جمعة 2-ماجد محمد سعد 3-هند عبداللاه محمود 4-هناء احمد ابوقوره }
$$

1-قســـم البيئه والزراعه الحيوية كليه الزراعة بالقاهرة جامعه الأزهر. 2- معهد بحوث الهندســهـ الوراثيه مركز البحوث

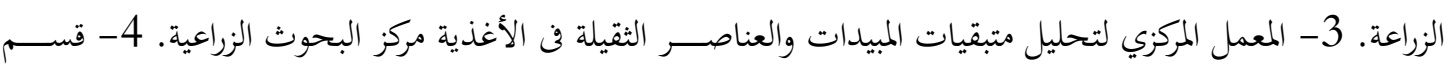

$$
\text { الميكروبيولوجيا معهد بحوث الاراضي والمياه والبيئه مركزالبحوث الزراعية. }
$$

النيونيكوتينويد مبيدات حشـــيه بتحاريه تسـتخدم علي نطاق واسـع في الزراعه وتعتبر من ملوثات البيئه. هذه المبيدات تحدث سميه في البيئه للانسان ولذلك يجب أن فتم هما إهتماماً كبيراً. في هذه الدراسه تم عزل خمسه عشره عزله ميكروبية من التربه وتم اختبارها لتكسير مبيد الاسيتاميريد في بيئه تحتوي عليه كمصدر وحيد للكربون ـ تم تعريف السلاله الاكثر

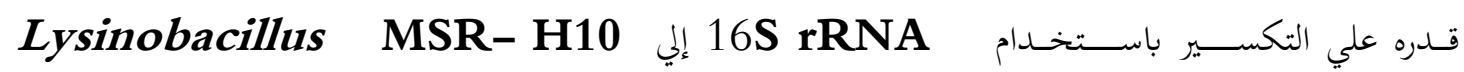
Macrolides أن سلاله Lysinobacillus macrolides لها القدره علي النمو في مدي واسع من الحموضه والحراره وسرعه الرج ومن المثير للإهتمام ان البكتيريا المغلفه بألجينات الصوديوم سجلت أعلي نتائج بالمقارنه بالبكتيريا في الصوره السـائلة كما كان لها القدره علي النمو في نوعي التربه الملوثه بالتركيزات المختلفه من المبيد . كما اتضــــ من النتائج ان البكتيريا في الصــوره المغلفه كان لها القدره علي تكسـير المبيد دون ان تحدث اي نقص في كفأعها وكانت أعلي كفاءة لإستخدام سلاله Lysinobacillus macrolides في تكسير مبيد الاسيتاميريد عند تركيز 5 بحم / لتر بعد 21 يومًا من التحضين في التربة الطينية. 